\title{
Control for Pollutant Emission from Diesel Engine Vehicles by Fuel Modification (Part 4)
}

\author{
Effect of Fuel Composition on the Emission of Benzo(a)pyrene
}

\author{
Akira Овuchi*, Akihiko Ohi, Hyogoro Aoyama, and Hideo Ohuchi \\ National Research Institute for Pollution and Resources, \\ Onogawa 16-3, Yatabe-cho, Tsukuba-gun, Ibaraki 305
}

(Received October 31, 1984)

\begin{abstract}
Effects of the composition of the fuel on the emission of benzo(a)pyrene $(\mathrm{B}(\mathrm{a}) \mathrm{P})$ from a diesel engine were investigated using a single cylinder test engine and 1) pure hydrocarbon-mixed fuels composed of $n$-cetane, heptamethylnonane $(\mathrm{HMN}), \alpha$-methylnaphthalene and a cetane number improver and 2) subfraction-mixed fuels composed of $n$-cetane, HMN and subfractions of diesel fuels prepared by fractional distillation and chromatographic separation. Aromaticity (aromatic carbon content) of the fuel was the principal factor for $\mathrm{B}(\mathrm{a}) \mathbf{P}$ emission, that is, $\mathrm{B}(\mathrm{a}) \mathrm{P}$ emission rate generally increased with the aromaticity of the fuel. Further effects by cetane number, boiling range and the content of $\mathrm{B}(\mathrm{a}) \mathrm{P}$ in the fuel were also considered.
\end{abstract}

\section{Introduction}

Control of pollutant emission, especially the particulate matter and nitrogen oxides, from dieselpowered vehicles is becoming an urgent problem for the protection of the atmospheric environment. ${ }^{1)}$ The authors have been conducting fundamental experiments for reducing pollutant emissions from diesel engines by fuel modification and have already reported on structural analysis of diesel fuels using proton and carbon-13 nuclear magnetic resonance spectroscopy $(\mathrm{NMR})^{2}$, and on combustion experiments of pure hydrocarbon-mixed fuels $^{3)}$ and subfraction-mixed fuels ${ }^{4}$ ) using a CFR F-5 single cylinder test engine.

The results of these experiments are summarized as follows: The average number of structural components in a diesel fuel molecule, such as methyl group $\left(-\mathrm{CH}_{3}\right)$, paraffinic or naphthenic methylene group $\left(-\mathrm{CH}_{2}-\right)$, aromatic carbon, can be determined by combining the NMR method with the traditional oil analysis method. From the combustion experiments using pure hydrocarbon-mixed fuels, of which molecular structures are fully known, it was found that the increase in the aromatic carbon content in the fuel results in increases in the emission of carbon monoxide, nitrogen oxides and particulate matter. From the combustion experiments

* To whom correspondence should be addressed. using the subfraction-mixed fuels, boiling range of the fuel was found to have little effect on gaseous emission.

Recently much attention has been focused on the emission of organic substances contained in diesel exhaust particulate matter, because some of them are suspected to be carcinogenic substances.5) Polycyclic aromatic hydrocarbons $(\mathrm{PAH})$ and their nitro substitutes $\left.{ }^{6}\right)$ are presently of particular concern. Therefore, it is necessary not only to measure the total amount of the particulate matter but also to determine the amount of these harmful substances when a new device or countermeasure for reducing diesel exhaust emission is developed.

The authors have developed a method to determine the amount of PAH contained in the particulate matter or diesel fuel, using high performance liquid chromatography(HPLC) with fluorescent spectroscopic detection.? In this paper, we will report the effect of certain fuel properties, such as cetane number, boiling range and the content of aromatic carbon, $\mathrm{B}(\mathrm{a}) \mathrm{P}$ itself and a cetane number improver on the emission of $B(a) P$, which is the most representative substances in many carcinogenic PAHs.

\section{Experimental}

\subsection{Sample}

Two sets of fuels, pure hydrocarbon-mixed fuels 
and subfraction-mixed fuels, were used as the sample. Details of the preparation method and the properties of these fuels were explained in the previous papers. ${ }^{2) ~ 4)}$ The pure hydrocarbon-mixed fuels were composed of $n$-hexadecane ( $n$-cetane), 2,2,4,4,6,8,8-heptamethylnonane(HMN), $\alpha$-methylnaphthalene $(\alpha-\mathrm{MN}) \quad$ (Tokyo Kasei Co., Ltd, Special Grade) and/or Diesel Ignition Improver 2 (DII-2, Ethyl Corp.), and were tested in order to find the effects on emissions of ternary or quaternary paraffinic carbon, aromatic carbon and a cetane number improver in the fuel. The composition and the cetane number of these fuels are summarized in Table 1. The subfraction-mixed fuels were composed of $n$-cetane, HMN and subfractions of diesel fuels, which were of particular boiling ranges (200-240, 240-280, 280-320 and $320-360^{\circ} \mathrm{C}$, symbolized as $20,24,28$ and 32, respectively) and structural types (saturates and aromatics, symbolized as $\mathrm{S}$ and Ar, respectively). This set of fuels was tested in order to find the effects of aromatic carbon content and the boiling range of the fuel on the emissions. The composition and some properties of these fuels are summarized in Table 2. The aromatic-rich gas oil, whose properties were investigated previously ${ }^{2}$, is an equivalent mixture of an Arabian Light rerun and direct distillate of a Sumatran oil. The content of $\mathrm{B}(\mathrm{a}) \mathrm{P}$ was measured using the HPLG. ${ }^{7)}$

\subsection{Analysis of $\mathbf{B}(\mathbf{a}) \mathbf{P}$}

The analytic procedure for $\mathrm{B}(\mathrm{a}) \mathrm{P}$ is shown in Fig. 1 as a flow chart. The diesel exhaust partic-

Table 1 Composition and Properties of Pure Hydrocarbon-mixed Fuels

\begin{tabular}{|c|c|c|c|c|c|c|c|}
\hline Fuel & $n-\mathrm{C}^{\mathrm{a})}$ & $\begin{array}{l}\text { Composition } \\
\text { HMNb) }\end{array}$ & $\begin{array}{l}(\mathrm{vol} \%) \\
\alpha-\mathrm{MNc})\end{array}$ & DII-2d) & $\begin{array}{l}\text { Cetane } \\
\text { Number }\end{array}$ & $\begin{array}{l}\text { Specific Gravity } \\
\left(20 / 4^{\circ} \mathrm{C}\right)\end{array}$ & Aromaticity \\
\hline $\begin{array}{l}\text { H0 } \alpha 0 \\
\text { H20 } \\
\text { H35 } \\
\text { H53 } \\
\text { H82 }\end{array}$ & $\begin{array}{r}100.00 \\
80.00 \\
64.71 \\
47.06 \\
17.65\end{array}$ & $\begin{array}{r}0.00 \\
20.00 \\
35.29 \\
52.94 \\
82.35\end{array}$ & $\begin{array}{l}0.00 \\
0.00 \\
0.00 \\
0.00 \\
0.00\end{array}$ & $\begin{array}{l}0.00 \\
0.00 \\
0.00 \\
0.00 \\
0.00\end{array}$ & $\begin{array}{r}100 \\
83 \\
70 \\
55 \\
30\end{array}$ & $\begin{array}{l}0.7745 \\
0.7763 \\
0.7777 \\
0.7797 \\
0.7835\end{array}$ & $\begin{array}{l}0 \\
0 \\
0 \\
0 \\
0\end{array}$ \\
\hline $\begin{array}{ll}\alpha & 5 \\
\alpha & 15 \\
\alpha & 30 \\
\alpha & 45 \\
\alpha & 70\end{array}$ & $\begin{array}{l}95.00 \\
85.00 \\
70.00 \\
55.00 \\
30.00\end{array}$ & $\begin{array}{l}0.00 \\
0.00 \\
0.00 \\
0.00 \\
0.00\end{array}$ & $\begin{array}{r}5.00 \\
15.00 \\
30.00 \\
45.00 \\
70.00\end{array}$ & $\begin{array}{l}0.00 \\
0.00 \\
0.00 \\
0.00 \\
0.00\end{array}$ & $\begin{array}{l}95 \\
85 \\
70 \\
55 \\
30\end{array}$ & $\begin{array}{l}0.7872 \\
0.8113 \\
0.8495 \\
0.8850 \\
0.9473\end{array}$ & $\begin{array}{l}0.064 \\
0.184 \\
0.347 \\
0.492 \\
0.700\end{array}$ \\
\hline $\begin{array}{l}\mathrm{H} 47 \propto 5 \\
\mathrm{H} 35 \alpha 15 \\
\mathrm{H} 18 \alpha 30\end{array}$ & $\begin{array}{l}47.94 \\
49.71 \\
52.35\end{array}$ & $\begin{array}{l}47.06 \\
35.29 \\
17.65\end{array}$ & $\begin{array}{r}5.00 \\
15.00 \\
30.00\end{array}$ & $\begin{array}{l}0.00 \\
0.00 \\
0.00\end{array}$ & $\begin{array}{l}55 \\
55 \\
55\end{array}$ & $\begin{array}{l}0.7913 \\
0.8150 \\
0.8491\end{array}$ & $\begin{array}{l}0.064 \\
0.184 \\
0.346\end{array}$ \\
\hline $\begin{array}{l}\text { H80D4 } \\
\text { H88D8 } \\
\text { H85D } 15\end{array}$ & $\begin{array}{r}16.34 \\
4.59 \\
0.00\end{array}$ & $\begin{array}{l}79.81 \\
87.15 \\
85.47\end{array}$ & $\begin{array}{l}0.00 \\
0.00 \\
0.00\end{array}$ & $\begin{array}{r}3.85 \\
8.26 \\
14.53\end{array}$ & $\begin{array}{l}55 \\
55 \\
55\end{array}$ & $\begin{array}{l}0.7911 \\
0.8005 \\
0.8130\end{array}$ & $\begin{array}{l}0 \\
0 \\
0\end{array}$ \\
\hline
\end{tabular}

a) $n$-cetane, b) $2,2,4,4,6,8,8$-heptamethylnonane, c) $\alpha$-methylnaphthalene, d) Diesel Ignition Improver 2

Table 2 Composition and Properties of Subfraction-mixed Fuels

\begin{tabular}{|c|c|c|c|c|c|c|c|}
\hline \multirow{2}{*}{ Fuel } & \multicolumn{3}{|c|}{ Composition (vol\%) } & \multirow{2}{*}{$\begin{array}{l}\text { Cetane } \\
\text { Number }\end{array}$} & \multirow{2}{*}{$\begin{array}{c}\text { Specific } \\
\text { Gravity } \\
\left(20 / 4^{\circ} \mathrm{C}\right)\end{array}$} & \multirow{2}{*}{$\begin{array}{c}\text { Concentration of } \\
\text { Benzo (a) pyrene } \\
(\mathrm{mg} / \mathrm{l})\end{array}$} & \multirow{2}{*}{ Aromaticity } \\
\hline & $\Sigma^{a)}$ & $n-\mathrm{C}^{\mathrm{b})}$ & $\mathrm{HMNc}$ & & & & \\
\hline $\begin{array}{l}F\left(\sum 20 S\right) 25 \\
F\left(\sum 20 S\right) 50 \\
F\left(\sum 24 S\right) 25 \\
F\left(\sum 24 S\right) 50 \\
F\left(\sum 28 S\right) 25 \\
F\left(\sum 28 S\right) 50 \\
F\left(\sum 32 S\right) 25 \\
F\left(\sum 32 S\right) 50\end{array}$ & $\begin{array}{l}25.0 \\
50.0 \\
25.0 \\
50.0 \\
25.0 \\
50.0 \\
25.0 \\
50.0\end{array}$ & $\begin{array}{r}35.7 \\
24.3 \\
32.1 \\
18.2 \\
29.3 \\
11.4 \\
28.0 \\
8.9\end{array}$ & $\begin{array}{l}39.3 \\
25.7 \\
41.9 \\
31.8 \\
45.7 \\
38.6 \\
47.0 \\
41.1\end{array}$ & $\begin{array}{l}\frac{-}{54} \\
\frac{54}{54} \\
\frac{54}{54}\end{array}$ & $\begin{array}{l}0.7850 \\
0.7904 \\
0.7848 \\
0.7902 \\
0.7861 \\
0.7927 \\
0.7895 \\
0.7997\end{array}$ & $\begin{array}{l}0.008 \\
0.016 \\
0.010 \\
0.019 \\
0.007 \\
0.013 \\
0.009 \\
0.019\end{array}$ & $\begin{array}{r}0.005 \\
0.011 \\
<0.001 \\
<0.001 \\
<0.001 \\
<0.001 \\
<0.001 \\
<0.001\end{array}$ \\
\hline $\begin{array}{l}\mathrm{F}\left(\sum 20 \mathrm{Ar}\right) 25 \\
\mathrm{~F}\left(\sum 20 \mathrm{Ar}\right) 50 \\
\mathrm{~F}\left(\sum 24 \mathrm{Ar}\right) 25 \\
\mathrm{~F}\left(\sum 24 \mathrm{Ar}\right) 50 \\
\mathrm{~F}\left(\sum 28 \mathrm{Ar}\right) 25 \\
\mathrm{~F}\left(\sum 28 \mathrm{Ar}\right) 50 \\
\mathrm{~F}\left(\sum 32 \mathrm{Ar}\right) 25 \\
\mathrm{~F}\left(\sum 32 \mathrm{Ar}\right) 50\end{array}$ & $\begin{array}{l}25.0 \\
50.0 \\
25.0 \\
50.0 \\
25.0 \\
50.0 \\
25.0 \\
50.0\end{array}$ & $\begin{array}{l}47.1 \\
47.2 \\
47.2 \\
47.3 \\
45.1 \\
43.2 \\
41.9 \\
36.8\end{array}$ & $\begin{array}{r}27.9 \\
2.8 \\
27.8 \\
2.7 \\
29.9 \\
6.8 \\
33.1 \\
13.2\end{array}$ & $\begin{array}{l}\overline{48} \\
- \\
- \\
\overline{-} \\
\overline{48}\end{array}$ & $\begin{array}{l}0.8107 \\
0.8435 \\
0.8207 \\
0.8627 \\
0.8224 \\
0.8656 \\
0.8197 \\
0.8606\end{array}$ & $\begin{array}{l}0.011 \\
0.022 \\
0.010 \\
0.019 \\
0.007 \\
0.013 \\
0.012 \\
0.024\end{array}$ & $\begin{array}{l}0.168 \\
0.318 \\
0.169 \\
0.316 \\
0.142 \\
0.282 \\
0.126 \\
0.237\end{array}$ \\
\hline $\begin{array}{l}\text { Ad) } \\
\text { A 55e) } \\
\text { F g) }\end{array}$ & $\overline{63 .}^{\mathrm{f})}$ & $\begin{array}{l}-\overline{36.6} \\
-\end{array}$ & $\begin{array}{l}- \\
- \\
-\end{array}$ & $\begin{array}{l}29 \\
54 \\
52\end{array}$ & $\begin{array}{l}0.8629 \\
0.8293 \\
0.8307\end{array}$ & $\begin{array}{l}5.38 \\
3.41 \\
1.91\end{array}$ & $\begin{array}{l}0.360 \\
0.240 \\
0.130\end{array}$ \\
\hline
\end{tabular}

a) subfraction, b) n-cetane, c) 2,2,4,4,6,8,8-heptamethylnonane, d) aromatic-rich gas oil,

e) cetane number-adjusted aromatic-rich gas oil, f) content of the aromatic-rich gas oil, g) commercial diesel fuel 


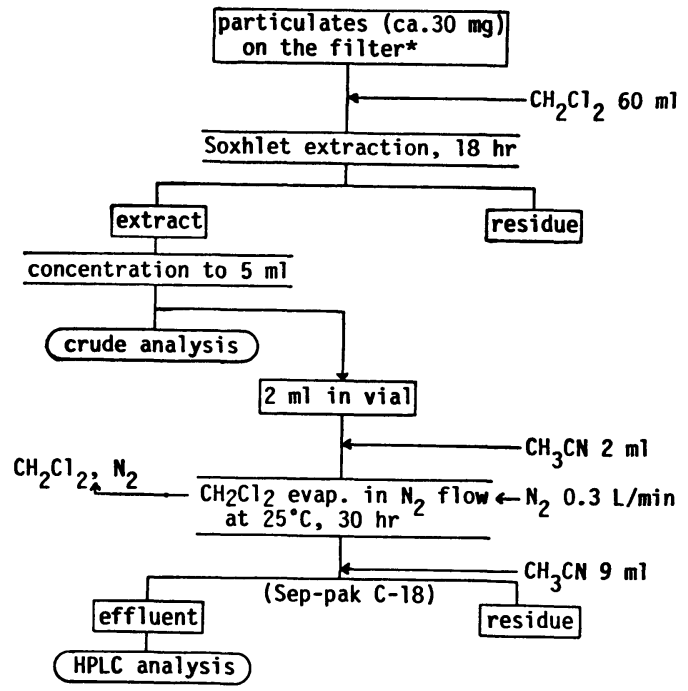

* Pallflex Prod. Corp. TX4OHI20-WW, $142 \mathrm{~mm} \phi$

Fig. 1 Pretreatment Procedure for B(a)P Analysis

ulate matter, which contains $\mathrm{B}(\mathrm{a}) \mathrm{P}$, was trapped on a Teflon-coated glass fiber filter (Pallflex Corp., TX40HI20-WW, $142 \mathrm{~mm} \phi$ ). The loaded filter was extracted with dichloromethane for 12 hours, and the extract was concentrated and dried. Then acetonitrile was added to the residue and the solution was passed through a preparation column (Waters Associates., Sep-Pak C-18). Finally, the eluate was analyzed using a HPLC with a fluorescent spectroscopic detector. The chromatographic conditions for $\mathrm{B}(\mathrm{a}) \mathrm{P}$ analysis are summarized in Table 3. Details of this analytic procedure have been reported elsewhere.7)

\subsection{Engine System}

The engine used was a CFR F-5 single cylinder
Table 3 Chromatographic Conditions for PAH Analysis

\begin{tabular}{ll}
\hline pump & $:$ Altex Scientific Inc. 101 A \\
injection device $:$ Kyowa Seimitsu Co., Ltd., Autosampler & KSST-60J, sample volume $=40 \mu l$ \\
column & $:$ Beckman, ODS column Ultrasphere- \\
& ODS $4.6 \times 250 \mathrm{~mm}$ \\
mobile phase & $: 70 / 30(\mathrm{v} / \mathrm{v})$ acetonitrile/water at 1.0 \\
& ml/min, deoxygenated by bubbling \\
& with helium \\
detector & Shimadzu Corp., Fluorescence spectro- \\
& monitor RF-530, ex. wave length $=330$ \\
& nm, em. wave length $=430 \mathrm{~nm}$ \\
data collection & $:$ System Instruments Co., Ltd., Chroma- \\
& togram processor 7000 AS \\
\hline
\end{tabular}

test engine for measuring cetane number (ASTM D 613 or JIS K 2280). The exhaust was lead to a dilution tunnel (Horiba Seisakusho Co. Ltd., DLT-09S), obtaining a 1 in 13 dilution, approximately. The diluted exhaust was filtrated with $47 \mathrm{~mm} \phi$ and $142 \mathrm{~mm} \phi$ filters, by which the emission rate of the particulate matter and its content of $\mathbf{B}(\mathrm{a}) \mathbf{P}$ were measured. This system was also equipped with an automobile exhaust gas analyzer (Horiba, MEXA 2000) for measuring concentrations of total hydrocarbon(THC), carbon monoxide $(\mathrm{CO})$, nitrogen oxides $\left(\mathrm{NO}_{x}\right)$ and carbon dioxide $\left(\mathrm{CO}_{2}\right)$, and an electrostatic aerozol analyzer (Nihon Kagaku Kogyo, MODEL 3030) for measuring the size and number of the particulate matter. The schematic diagram of the engine system is shown in Fig. 2. The results of the measurements, except those for $\mathrm{B}(\mathrm{a}) \mathrm{P}$, were reported in the previous papers.

The operating condition of the engine was the



Fig. 2 Schematic Diagram of the Engine and Sampling Systems 
Table 4 Reproducibility of B (a) P Measurement

\begin{tabular}{c|cc}
\hline \multirow{2}{*}{ No. } & \multicolumn{2}{|c}{ B (a) P Emission Rate $(\mathrm{ng} / \mathrm{min})$} \\
& H53 & F \\
\hline 1 & 4.8 & 34.3 \\
2 & 6.4 & 64.0 \\
3 & 7.4 & 22.8 \\
4 & 4.9 & 29.9 \\
5 & 6.8 & 53.6 \\
6 & 5.8 & 49.9 \\
7 & 7.1 & 20.9 \\
8 & 4.0 & 53.0 \\
9 & 2.7 & \\
10 & 2.5 & \\
& 5.4 & 41.1 \\
mean & 1.5 & 16.1 \\
s. d.a) & 29 & 39 \\
c. v. ${ }^{\text {b) }}$ (\%) & & \\
\hline
\end{tabular}

a) s. d. : standard deviation

b) c. v. : coefficient of variation

same as that for measuring cetane number, except for the compression ratio and the fuel flow rate. The compression ratio was set at 16.0.

The fuel flow rate was set at $15 \mathrm{ml} / \mathrm{min}$ for the experiments on pure hydrocarbon-mixed fuels, and varied from 14.6 to $16.0 \mathrm{ml} / \mathrm{min}$ for the subfractionmixed fuels by keeping the excess air ratio constant at 1.35 , which was estimated by real time measurement of $\mathrm{CO}_{2}, \mathrm{CO}$ and $\mathrm{THC}$ exhaust concentrations and calculation according to Holl's equation.8) The engine was warmed up for more than 3 hours before the experiment. In addition, about $15 \mathrm{~min}$ of preliminary operation with each test fuel always preceded the sampling of the particulate matter, which lasted 20-25 min.

The total reproducibility of the $\mathrm{B}(\mathrm{a}) \mathrm{P}$ measurement from engine operation to the HPLC analysis was examined using fuel $\mathrm{H} 53$ and F (Table 4), which was estimated to be $29 \%$ and $39 \%$, respectively, as the coefficient of variation. The engine condition is thought to be the principal factor for the variation.

\section{Results}

\subsection{B(a)P Emisson from the Pure Hydro- carbon-mixed Fuels}

All the results concerning particulate and $\mathrm{B}(\mathrm{a}) \mathbf{P}$ emissions by combustion of pure hydrocarbon-mixed fuels are summarized in Table 5, where $\mathrm{B}(\mathrm{a}) \mathbf{P}$ emission rates were estimated from particulate emission rates and $B(a) P$ contents in the particulate matter.

Fuels $\mathrm{H} 0 \alpha 0$ to $\mathrm{H} 82$ are binary mixtures of $n$-cetane and HMN so that these fuels are purely paraffinic. As the content of HMN increases, ternary and quaternary carbon structure increases and cetane number decreases (see Table 1). As shown in Table 5, B(a) $\mathrm{P}$ emission rates ranged from 5 to $12 \mathrm{ng} / \mathrm{min}$ for these fuels, and there is no definite tendency towards $\mathrm{HMN}$ content.

Fuels $\alpha 5$ to $\alpha 70$ are binary mixtures of $n$-cetane and $\alpha-\mathrm{MN}$. As $\alpha-\mathrm{MN}$ content increases, aromaticity of the mixture increases and the cetane number decreases (see Table 1). The particulate emission rate was maximum at $\alpha 30$, while $\mathrm{B}(\mathrm{a}) \mathrm{P}$ content in the particulate matter roughly increased with the $\alpha-\mathrm{MN}$ content in the fuel. $\mathrm{B}(\mathrm{a}) \mathrm{P}$ emission rates ranged from 7 to $210 \mathrm{ng} / \mathrm{min}$, one order of magnitude larger than those for the purely paraffinic fuels, except for $\alpha 5$.

Fuels $\mathrm{H} 47 \propto 5$ to $\mathrm{H} 18 \alpha 30$ are ternary mixtures of $n$-cetane, HMN and $\alpha-\mathrm{MN}$, keeping the cetane number constant at 55. For fuel $\mathrm{H} 18 \propto 30, \mathrm{~B}(\mathrm{a}) \mathrm{P}$ emission rate was definitely large compared with the purely paraffinic fuels, due to the increase in both the particulate emission rate and the $B(a) P$

Table 5 Particulate and B(a) P Emissions by Combustion of Pure Hydrocarbon-mixed Fuels

\begin{tabular}{|c|c|c|c|}
\hline Fuel & $\begin{array}{l}\text { Particulate } \\
\text { Emission Rate } \\
\text { (mg/min) }\end{array}$ & $\begin{array}{l}\text { B(a) P Content in the } \\
\text { Particulate Matter } \\
\text { (ppm) }\end{array}$ & $\begin{array}{l}\text { B (a) P } \\
\text { Emission Rate } \\
\text { (ng/ min })\end{array}$ \\
\hline $\begin{array}{l}\mathrm{H} 0 \alpha 0 \\
\mathrm{H} 29 \\
\mathrm{H} 35 \\
\mathrm{H} 53 \\
\mathrm{H} 82\end{array}$ & $\begin{array}{l}27.2 \\
20.8 \\
22.7 \\
24.5 \pm 2.7 \\
13.2\end{array}$ & $\begin{array}{l}0.26 \\
0.59 \\
0.20 \\
0.22 \pm 0.06 \\
0.77\end{array}$ & $\begin{array}{c}7.1 \\
12.3 \\
4.5 \\
5.4 \pm 1.5 \\
10.1\end{array}$ \\
\hline $\begin{array}{l}\alpha 5 \\
\alpha 15 \\
\alpha 30 \\
\alpha 45 \\
\alpha 70\end{array}$ & $\begin{array}{l}29.8 \\
53.6 \\
67.9 \\
52.0 \pm 5.1 \\
25.6\end{array}$ & $\begin{array}{l}0.25 \\
1.77 \\
3.09 \\
2.10 \pm 0.51 \\
3.25\end{array}$ & $\begin{array}{c}7.4 \\
94.8 \\
210 \\
111 \pm 37 \\
83.2\end{array}$ \\
\hline $\begin{array}{l}\mathrm{H} 47 \propto 5 \\
\mathrm{H} 35 \propto 15 \\
\mathrm{H} 18 \propto 30\end{array}$ & $\begin{array}{l}28.9 \\
36.0 \\
54.8\end{array}$ & $\begin{array}{l}0.48 \\
0.37 \\
1.14\end{array}$ & $\begin{array}{l}13.8 \\
13.3 \\
62.5\end{array}$ \\
\hline $\begin{array}{l}\text { H80D4 } \\
\text { H88D8 } \\
\text { H85D } 15\end{array}$ & $\begin{array}{l}24.5 \\
24.4 \\
21.6\end{array}$ & $\begin{array}{l}0.35 \\
0.29 \\
0.40\end{array}$ & $\begin{array}{l}8.6 \\
7.1 \\
8.6\end{array}$ \\
\hline
\end{tabular}


Table 6 Particulate and B(a) P Emissions by the Combustion of Subfraction-mixed Fuels

\begin{tabular}{|c|c|c|c|}
\hline Fuel & $\begin{array}{l}\text { Particulate } \\
\text { Emission Rate } \\
\text { (mg/min) }\end{array}$ & $\begin{array}{l}\text { B (a) P Content in the } \\
\text { Particulate Matter } \\
\text { (ppm) }\end{array}$ & $\begin{array}{l}\mathrm{B}(\mathrm{a}) \mathrm{P} \\
\text { Emission Rate } \\
\text { (ng/ min) }\end{array}$ \\
\hline $\begin{array}{l}\mathrm{F}\left(\sum 20 \mathrm{~S}\right) 25 \\
\mathrm{~F}\left(\sum 20 \mathrm{~S}\right) 50 \\
\mathrm{~F}\left(\sum 24 \mathrm{~S}\right) 25 \\
\mathrm{~F}\left(\sum 24 \mathrm{~S}\right) 50 \\
\mathrm{~F}\left(\sum 28 \mathrm{~S}\right) 25 \\
\mathrm{~F}\left(\sum 28 \mathrm{~S}\right) 50 \\
\mathrm{~F}\left(\sum 32 \mathrm{~S}\right) 25 \\
\mathrm{~F}\left(\sum 32 \mathrm{~S}\right) 50\end{array}$ & $\begin{array}{l}23.5 \\
22.0 \\
24.3 \\
23.7 \\
23.7 \\
23.5 \\
25.9 \\
29.3\end{array}$ & $\begin{array}{l}0.36 \\
0.46 \\
0.21 \\
0.22 \\
0.27 \\
0.33 \\
0.14 \\
0.13\end{array}$ & $\begin{array}{r}8.4 \\
10.1 \\
5.1 \\
5.2 \\
6.4 \\
7.7 \\
3.6 \\
3.8\end{array}$ \\
\hline $\begin{array}{l}\mathrm{F}\left(\sum 20 \mathrm{Ar}\right) 25 \\
\mathrm{~F}\left(\sum 20 \mathrm{Ar}\right) 50 \\
\mathrm{~F}\left(\sum 24 \mathrm{Ar}\right) 25 \\
\mathrm{~F}\left(\sum 24 \mathrm{Ar}\right) 50 \\
\mathrm{~F}\left(\sum 28 \mathrm{Ar}\right) 25 \\
\mathrm{~F}\left(\sum 28 \mathrm{Ar}\right) 50 \\
\mathrm{~F}\left(\sum 32 \mathrm{Ar}\right) 25 \\
\mathrm{~F}\left(\sum 32 \mathrm{Ar}\right) 50\end{array}$ & $\begin{array}{l}30.8 \\
51.1 \\
35.8 \\
51.4 \\
32.6 \\
54.2 \\
27.5 \\
39.1\end{array}$ & $\begin{array}{l}0.20 \\
0.67 \\
0.18 \\
1.61 \\
0.45 \\
1.97 \\
0.37 \\
0.60\end{array}$ & $\begin{array}{r}6.2 \\
34.3 \\
6.4 \\
82.8 \\
14.7 \\
106.8 \\
10.2 \\
23.4\end{array}$ \\
\hline $\begin{array}{l}A^{a)} \\
\left.A^{a} 55^{b}\right) \\
F^{c)}\end{array}$ & $\begin{array}{l}18.3 \\
38.4 \\
42.2 \pm 3.3\end{array}$ & $\begin{array}{l}0.88 \\
0.23 \\
0.96 \pm 0.35\end{array}$ & $\begin{array}{l}16.1 \\
8.8 \\
41.1 \pm 16.1\end{array}$ \\
\hline
\end{tabular}

a) aromatic-rich gas oil

b) cetane number-adjusted aromatic-rich gas oil

c) commercial diesel fuel

content.

Fuels H80D4 to H85D15 are purely paraffinic fuels doped with the cetane number improver, setting the cetane number around 55. As shown in the table, the cetane number improver had no influence on the particulate and $\mathrm{B}(\mathrm{a}) \mathrm{P}$ emissions, since these values are in the same order as those for the non-doped fuels $(\mathrm{H} 0 \alpha 0-\mathrm{H} 82)$.

\section{2 $B(a) P$ Emission from the Subfraction- mixed Fuels}

All the results concerning particulate and $\mathrm{B}(\mathrm{a}) \mathrm{P}$ emissions by the combustion of the subfraction-mixed fuels are summarized in Table 6, in which the results for the commercial $(F)$ and the specially prepared aromatic-rich fuels (A, A55) are also listed.

Fuels $\mathrm{F}(\Sigma 20 \mathrm{~S}) 25$ to $\mathrm{F}\left(\sum 32 \mathrm{~S}\right) 50$ are mixtures of $n$-cetane, HMN and 25 or $50 \mathrm{vol} \%$ of saturate subfractions of diesel fuels. These fuels, therefore, are almost purely paraffinic. The results for these fuels were almost equal to those for the pure hydrocarbon-mixed, paraffinic fuels $(\mathrm{H} 0 \propto 0-\mathrm{H} 82)$, and there is no significant tendency towards boiling range or content of the subfractions.

Fuels $\mathrm{F}(\Sigma 20 \mathrm{Ar}) 25$ to $\mathrm{F}\left(\sum 32 \mathrm{Ar}\right) 50$ are mixtures of $n$-cetane, HMN and 25 or $50 \mathrm{vol} \%$ of the aromatic subfractions of diesel fuels. The emissions were mostly great compared with the saturate subfraction-mixed fuels or H53 in Table 5. Both particulate emission rate and $\mathrm{B}(\mathrm{a}) \mathrm{P}$ content were increased with the content of the aromatic subfraction for all the boiling ranges. As for the ef- fect of the boiling range, the emissions were maximum at $\mathrm{F}(\Sigma 28 \mathrm{Ar}) 50$, which contained the aromatic subfraction having a boiling range from 280 to $320^{\circ} \mathrm{C}$. We will consider this point later.

\section{Discussion}

There are several reports concerning the relationship between the fuel composition and the $\mathrm{B}(\mathrm{a}) \mathrm{P}$ or $\mathrm{PAH}$ emission from diesel engines. ${ }^{9)}$ 11) Henderson et al. studied PAH emission using 0.01$1 \%$-cetane solution of some PAHs as fuel and found that the content of pyrene in the exhaust particulate matter increased with its content in the fuel. ${ }^{9)}$ They pointed out that PAH species are liable to be emitted unburnt because their boiling points are higher than $n$-cetane. In our study, experiments to add known amounts of $\mathrm{B}(\mathrm{a}) \mathrm{P}$ purposely to the fuel and observe its emission rate were not conducted. However, B(a)P was found in the subfraction-mixed fuels and some original diesel fuels (see Table 2) so that it was possible to examine the effect of $\mathrm{B}(\mathrm{a}) \mathrm{P}$ contained in the fuel on its emission. Fig. 3 shows the B (a) $P$ emission rate as a function of $B(a) P$ supply rate with the fuel. There is no meaningful correlation between the two values in this figure. In addition, in the higher range of $\mathrm{B}(\mathrm{a}) \mathrm{P}$ supply rate, $\mathrm{B}(\mathrm{a}) \mathrm{P}$ is being greatly reduced during the combustion. On the other hand, in the case of pure hydrocarbon-mixed fuels, the fuels were free from $\mathrm{B}(\mathrm{a}) \mathrm{P}$ so that the $\mathrm{B}(\mathrm{a}) \mathrm{P}$ emitted in this instance was clearly the combustion-derived pro- 


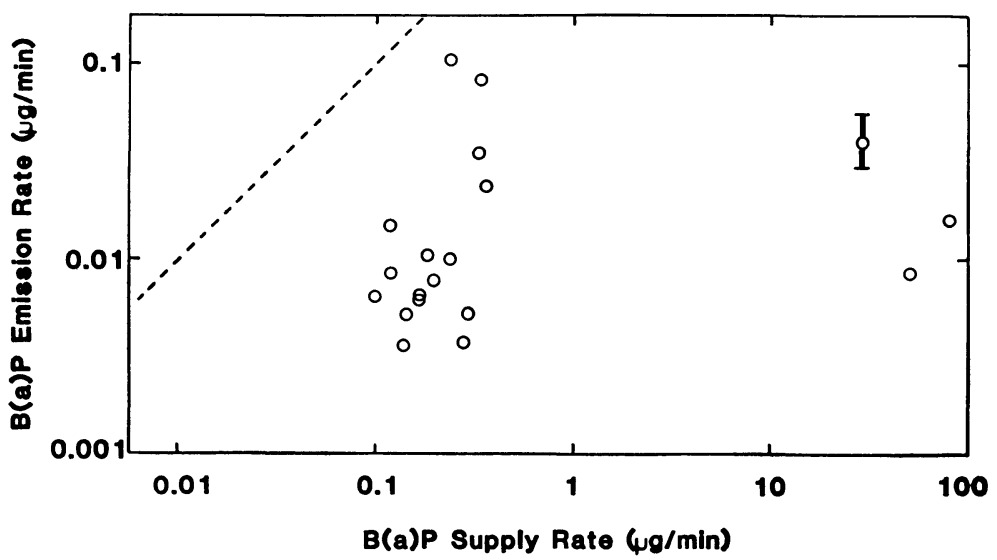

The supply and emission rates are equivalent on the dotted line.

Fig. 3 Relationship between the B(a)P Supply Rate with the Fuel and the B(a)P Emission Rate

duct in the engine. At any rate, it is concluded from these considerations that the content of $\mathbf{B}$ (a) $\mathrm{P}$ was not the principal factor for its emission in such low concentration range of $\mathrm{B}(\mathrm{a}) \mathrm{P}$ as in the case of our experiments and the emission level was more affected by other fuel and combustion characteristics.

As for the fuel properties, aromaticity was found to be the principal factor increasing $\mathrm{B}(\mathrm{a}) \mathrm{P}$ emission. In Fig. 4, B(a) $\mathrm{P}$ emission rates are exhibited as a function of aromatic carbon supply rate $\left(r_{\mathrm{a}}\right)$ with the fuel. $\mathrm{B}(\mathrm{a}) \mathrm{P}$ emission rate is increased roughly exponentially with $r_{\mathrm{a}}$. When the fuel is almost purely paraffinic, neither branching struc-

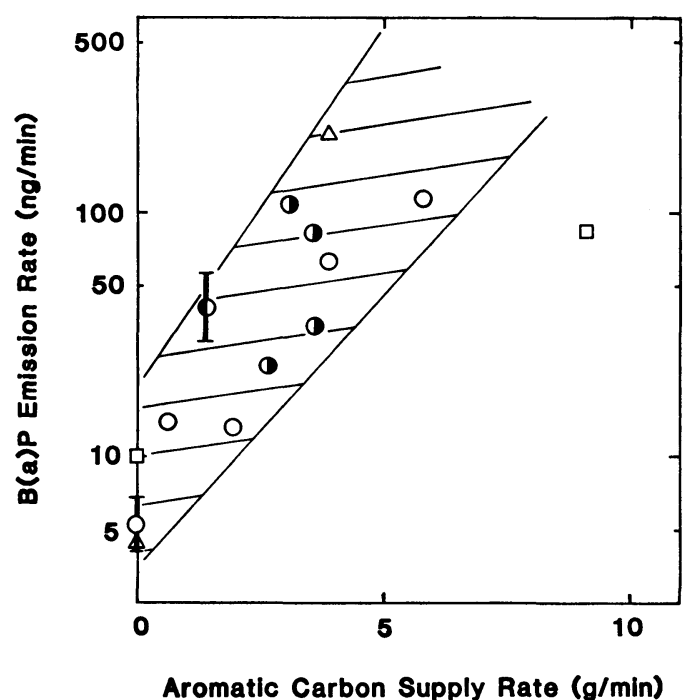

: Pure hydrocarbon-mixed fuels, cetane number $=55$ $\square$ : Pure hydrocarbon-mixed fuels, cetane number $=30$ $\triangle:$ Pure hydrocarbon-mixed fuels, cetane number $=70$ (1) : The subfraction-mixed fuels, cetane number $=55$ D : Commercial diesel fuel (F), cetane number $=55$

Fig. 4 Relationship between the Aromatic Carbon Supply Rate and the B(a)P Emission Rate ture of the molecule, addition of the cetane number improver nor the boiling range had any effect on the particulate and $\mathbf{B}(\mathrm{a}) \mathbf{P}$ emissions as shown in Table 5 (H0 $\alpha 0-H 82$, H80D4-H85D15) and Table $6(\mathrm{~F}(\Sigma 20 \mathrm{~S}) 25-\mathrm{F}(\Sigma 32 \mathrm{~S}) 50)$.

In Fig. 4, the result for $\alpha 30$ (cetane number $=70$ ) deviates to upper side and that for $\alpha 70$ (cetane number $=30$ ) to lower side, so that cetane number of the fuel is thought to be another factor affecting the emission of $B(a) P$. However, further experiments are necessary to clarify this effect.

Mills et al. reported the effect of diesel fuel aromaticity on $\mathrm{PAH}$ emissions using a 2-cylinder engine. They tested specially blended gas oils which ranged in aromatic content from 10 to 70 $\%$, and found that the $\mathrm{PAH}$ emission rate (the sum of each amount of PAH examined, mainly

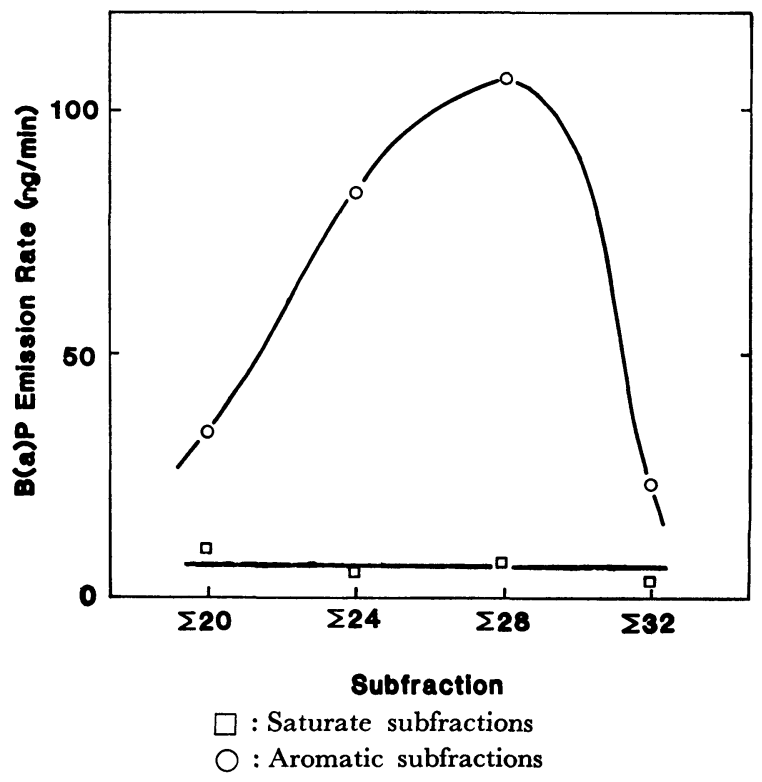

Fig. 5 The Results of the 50 vol\% Subfraction-mixed Fuels 
Table 7 Properties of Aromatic Subfraction

\begin{tabular}{c|ccc}
\hline Subfraction & $\begin{array}{c}\text { Specific } \\
\text { Gravity } \\
\left(15 / 4^{\circ} \mathrm{C}\right)\end{array}$ & $\begin{array}{c}\text { Aromatic Carbon } \\
\text { Number in a } \\
\text { Molecule }\end{array}$ & Aromaticity \\
\hline$\sum 20 \mathrm{Ar}$ & 0.9102 & 6.33 & 0.574 \\
$\sum 24 \mathrm{Ar}$ & 0.9474 & 7.52 & 0.537 \\
$\sum 28 \mathrm{Ar}$ & 0.9565 & 8.01 & 0.499 \\
$\sum 32 \mathrm{Ar}$ & 0.9453 & 7.49 & 0.423 \\
\hline
\end{tabular}

composed of smaller PAHs than chrysene) increased monotonously with the aromaticity of the fuel. Our results are in agreement with theirs.

Fig. 5 shows the results of $\mathrm{B}(\mathrm{a}) \mathrm{P}$ emission rate for the fuels containing $50 \mathrm{vol} \%$ of the subfraction. As for the fuels containing the aromatic subfractions, the variation range is great. In order to find the cause of this tendency, some fuel properties were considered, which are listed in Table 7. The Maxima of the specific gravity and average aromatic carbon number in a molecule $\left(C_{\mathrm{a}}\right)$ are at $\Sigma 28 \mathrm{Ar}$, which agree with the tendency of the $\mathrm{B}(\mathrm{a}) \mathrm{P}$ emission. $C_{\mathrm{a}}$ must be six for aromatic substances which contain only one benzene ring. The fact that $C_{\mathrm{a}}$ exceeds six means that there exist certain aromatic substances which contain some fused ring or plural number of benzene rings. The greater the $C_{\mathrm{a}}$ is, the higher is the content of such substances. These substances are thought to be more liable to change into $\mathrm{B}(\mathrm{a}) \mathrm{P}$ than simple benzene derivatives. It will be our next aim to clarify this point or to attempt to identify certain substance which especially participate in the formation of $\mathrm{B}(\mathrm{a}) \mathrm{P}$.

\section{Conclusion}

Effects of the fuel composition on the emission of benzo(a)pyrene $(B(a) P)$ were investigated using a CFR F-5 engine under an operating condition of a fixed fuel injection timing, revolution and fuel flow rate or excess air ratio, and using pure hydrocarbon-mixed fuels or subfraction-mixed fuels.

$\mathrm{B}(\mathrm{a}) \mathrm{P}$ emission rate generally increased with aromaticity of the fuel. Additional effects by cetane number and molecular structure were suggested for the fuels containing aromatics. In the case of almost purely paraffinic fuels, neither branching structure of the molecules, addition of the cetane number improver nor the boiling range had any effect on the particulate and $\mathrm{B}(\mathrm{a}) \mathrm{P}$ emissions. There was no evident relationship between the content of $\mathrm{B}(\mathrm{a}) \mathrm{P}$ in the fuel $(0.03-5 \mathrm{mg} / \mathrm{liter})$ and its emission rate.

\section{References}

1) Greeves, G., Wang, C.H.T., Soc. Automotive Eng. Paper No. 810260, (1981).

2) Ohuchi, H., Ohi, A., Aoyama, H., Sekiyu Gakkaishi, 25, (4), 205 (1982).

3) Ohi, A., Aoyama, H., Obuchi, A., Ohuchi, H., Sekiyu Gakkaishi, 27, (4), 303 (1984).

4) Ohi, A., Aoyama, H., Obuchi, A., Ohuchi, H., Sekiyu Gakkaishi, 27, (4), 313 (1984).

5) Barth, D. S., Blacker, S. M., J. Air Pollut. Contr. Assoc., 28, 769 (1978).

6) Tejada, S. B., Zweidinger, R. B., Sigsby, Jr, J. E., Soc. Automotive Eng., Paper No. 820775, (1982).

7) Obuchi, A., Aoyama, H., Ohi, A., Ohuchi, H., J. Chromatogr., 312, 247 (1984).

8) Holl, W. H., Soc. Automotive Eng., Paper No. 730533, (1973).

9) Henderson, T. R., Sun, J. D., Li, A. P., Hanson, R. L., Bechtold, W. E., Environ. Sci. Technol., 18, 428 (1984).

10) Mills, G. A., Howarth, J. S., Howard, A. G., J. Inst. Energy, 57, (430), 273 (1984).

11) Mills, G. A., Howard, A. G., J. Inst. Energy, 56, (428), 131 (1983). 


\title{
ティーゼル機関の燃料組成の改善による排出物啠の低減 （第 4 報）燃料組成のベンゾ(a)ピレン排出に及ぼす影響
}

\author{
小㴊 存, 大井 明彦, 青山兵五郎, 大内日出夫 \\ 公害資源研究所，305 茨城県筑波郡谷田部町小野川 16-3
}

ディーゼル車は, 燃料経済性が優れているために近年増加の 傾向にあるが，粒子状物質 (黒煙) と窒素酸化物の排出量が多 く, これらの有害物質による大気污染が問題となりつつある。1) とりわけ，粒子状物質については，発がん性の疑いのある有機 物質の存在が確認されており, その排出の実態を定量的に把握 することが望まれている。昼,6) 中でも，ベンジ(a)ピレン (B(a) P）は，発がん性を有する種々の多環芳香族炭化水素の代表的 な物質で，これの定量方法や生物化学的な性質は詳しく調べら れている。著者らは, ディーゼル然料の組成, 性状と排出物質 との間の詳細な関係を明らかにすることにより排出物質低減対 策に寄与するディーゼル然料の改変の方向を提示することを目 的とした研究を進めてきたが2) 4)，上述の理由により，新た に, 粒子状物質に含まれる $\mathrm{B}(\mathrm{a}) \mathrm{P}$ を分析の対象に加兄, 燃料 組成とその排出量との関係を調べた。

二組の燃料を試験に供した。第一は，3 種類の単一成分炭化 水素 $n$-セタン, ヘプタメチルノナン $(\mathrm{HMN}), 1$-メチルナフ タレン $(\alpha-\mathrm{MN})$ とセタン価向上剤 (DII-2, Ethyl 社製)を適 宜混合したもので (Table 1)，燃料の芳香族成分およびセタ ン価向上剤の含有量，セタン価が B ( a ) P の排出量に及ぼす影 響を調べた。第二は, 軽油相当留分の油を分留および分取ク口 マトグラフィーにより沸点範囲別，さらに飽和成分，芳香族成 分別に分けた試料を，セタン価 55 に合わせたもので (Table 2)，燃料の芳香族成分含有量および沸点が $\mathrm{B}(\mathrm{a}) \mathrm{P}$ の排出量に 及ぼす影響を調べた。B（a）P の分析手順は Fig. 1 に示す通 りで,ディーゼル機関の排出ガスを約 13 倍に希积した後, 142 $\mathrm{mm} \phi$ のガラス繊維円板ろ紙を通して粒子状物質を採取し，抽 出, 前処理の後, 蛍光検出器付の高速液体クロマトグラフィー で定量を行った（Tables 3, 4)。使用した機関は，七タン価測 定用 CFR F-5 ディーゼル機関（ASTM D613 または JIS K 2280) で, 圧縮比 16.0 , 燃料消費量 $15 \mathrm{ml} / \mathrm{min}$ (単一成分炭 化水素混合燃料の場合) または空気過剩率 1.35 (分割試料混 合然料の場合）以外の条件は，七タン価測定時のものと同じと した。機関を含む装置系を Fig. 2 に示す。

Table 5 に, 単一成分炭化水素混合燃料の燃焼に打ける粒 子状物質および B ( a )P 排出量の結果をまとめた。

$n$-セタンと HMN を混合した純パラフィン系燃料 $\mathrm{H} 0 \alpha 0$
H82 の場合，B（a ）P の排出量は 5 12 ng/min で， 2 成分の 混合比による変化は認められなかった。一方, $n$-セタンと $\alpha$ MN を混合した燃料 $\alpha 5 \sim \alpha 70$ の場合, B (a)P 排出量は $\alpha 5$

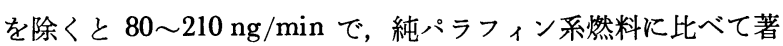
しく増加した。H47 $\alpha 5 \sim \mathrm{H} 18 \alpha 30$ は，セタン価を 55 に保った まま $n$-セタン, $\mathrm{HMN}, \alpha-\mathrm{MN}$ の混合比を变えたもので, 粒 子状物質および $\mathrm{B}(\mathrm{a}) \mathrm{P}$ 排出量は $\alpha-\mathrm{MN}$ を $30 \%$ 含む $\mathrm{H} 18 \alpha$ 30 のとき，純パラフィン系の $\mathrm{H} 0 \alpha 0 \sim \mathrm{H} 82$ と比べて明らかな 増加が認められた。H80D4〜H85D15 は $n$-七タンと HMN の 混合物にセタン価向上剂を添加した燃料で， $\mathrm{H} 0 \alpha 0 \sim \mathrm{H} 82$ との 比較からわかるように, セタン価向上剤の使用は粒子状物質, B (a ) P の排出量に何ら影響を及ぼさなかった。

Table 6 に, 分割試料混合燃料の燃焼に拈ける 粒子状物質 および B ( a ) P 排出量の結果をまとめた。

$\mathrm{F}(\Sigma 20 \mathrm{~S}) 25 \sim \mathrm{F}\left(\sum 32 \mathrm{~S}\right) 50$ は, 飽和成分の分割試料, $n$-七夕 ン, HMN から成る燃料で, 純パラフィン系に近い性状のもの である。これらの場合， B ( a ) P 排出量は単一成分炭化水素漉 合然料に抢ける純パラフィン系の $\mathrm{H} 0 \alpha 0 \sim \mathrm{H} 82$ と同様の小さい 値となり，また，分割試料ごとやその混合率による変化も認め られなかった。一方, F ( $220 \mathrm{Ar}) 25 \sim \mathrm{F}(\Sigma 32 \mathrm{Ar}) 50$ は芳香族成 分の分割試料, $n$-セタン, HMN から成る燃料で, B (a)P の 排出量は, 飽和成分を混合した燃料に比べて一般に大きく, 分 割試料の混合率とともに増加した。また，分割試料ごとの変化 も著しかったが，沸点範囲と単調な関係にはなかった。

以上の結果について次のような考察を行った。まず，燃料中 に含まれる B (a)P とその排出量の関係を調べたところ (Fig. 3), 報告例にあるような正の相関関係9) は認められなかった。こ れは, 本研究における然料中の $\mathrm{B}(\mathrm{a}) \mathrm{P}$ 排出量が報告例よりも 極端に低いためと思われる。次いで, 燃料の芳香族性と B(a) $\mathrm{P}$ 排出量の関係を調べ (Fig. 4), B ( a ) P 排出量が 芳香族成 分の供給量とともに指数関数的に増大することを見出した。こ の際, セタン価も B ( a ) P 排出量に影響を及ぼすことが示唆 された。さらに，芳香族成分の分割試料における 試料ごとの B (a ) P 排出量の違い(Fig. 5) は, 燃料中の芳香族成分の構 造の違いとよく対応すること（Table 7)，などを明らかにし た。

\section{Keywords}

Benzo(a)pyrene, Diesel fuel, Emission 